\title{
Pemenuhan Gizi dengan Kualitas Tidur pada Bayi Usia 6-9 Bulan di Puskesmas Bangsal Kabupaten Mojokerto
}

\author{
Ika Yuni Susanti, Dyah Siwi Hety* \\ Sekolah Tinggi Ilmu Kesehatan Majapahit Mojokerto, Indonesia \\ Corresponding author: Dyah Siwi Hety (dyahsiwi11@gmail.com) \\ Received: Mei, 20 2020; Accepted: June, 28 2020; Published: September, 12020
}

\begin{abstract}
ABSTRAK
Nutrisi memenuhi kebutuhan bayi pada usia 6-9 bulan dapat mempengaruhi kualitas tidurnya. Jika nutrisinya memenuhi kebutuhan yang cukup, maka tidak akan mengalami gangguan pada saat tidur.

Penelitian ini menggunakan pendekatan crossectional. Adapun variabel bebasnya adalah gizi memenuhi kebutuhan bayi usia 6-9 bulan dan kualitas tidur sebagai variabel terikatnya. Populasinya adalah bayi usia 6-9 bulan. Di Puskesmas Bangsal Kabupaten Mojokerto sebanyak 49 bayi. Sampel dipilih dengan menggunakan total sampling sebanyak 39 bayi. Pengumpulan data menggunakan wawancara untuk nutrisi memenuhi kebutuhan dan kualitas tidur. Data menggunakan pearson chi squre.

Hasil penelitian menunjukkan bayi usia 6 bulan sudah mengalami gizi mencukupi kebutuhan gizi kurang sebanyak 18 bayi $(46,2 \%)$, dan mengalami gangguan tidur sebanyak 15 bayi $(38,5)$. $\%)$. Selain itu, untuk bayi yang memenuhi kebutuhan gizi lebih sebanyak 9 bayi $(23,1 \%)$, semua bayi mengalami gangguan saat tidur. Kemudian bayi yang mendapat gizi cukup memenuhi kebutuhan sebanyak 12 bayi $(30,8 \%)$, sehingga yang mendapat gangguan tidur sebanyak 11 bayi $(28,2 \%)$.

Hasil uji pearson chi squre dengan menggunakan SPSS didapatkan nilai $\mathrm{P}$ Value Cremer's $\mathrm{V}=$ 0,0000 , kemudian nilai $\mathrm{P}$ Value $<\alpha(0,05)$. Sehingga dapat disimpulkan $\mathrm{H} 1$ diterima artinya ada hubungan antara terpenuhinya kebutuhan gizi dengan kualitas tidur bayi usia 6-9 bulan.

Pemenuhan kebutuhan nutrisi yang kurang atau lebih dapat mempengaruhi kualitas tidur bayi. Oleh karena itu, disarankan kepada petugas kesehatan khususnya bidan untuk memberikan penyuluhan kepada orang tua bayi tentang cara tepat memenuhi kebutuhan asupan gizi sekaligus dengan mengunjungi rumah untuk melihat hasil penyuluhan yang diberikan.
\end{abstract}

Kata Kunci: Nutrisi, Tidur, Bayi

This is an open-acces article distributed under the terms of the Creative Commons Attribution-ShareAlike 4.0 International License.

\section{PENDAHULUAN}

Melalui makanan manusia mendapatkan zat gizi yang merupakan kebutuhan dasar untuk tumbuh dan berkembang (Husaini, 2002). Ketidaktahuan tentang cara pemberian makan pada bayi baik dari jumlah, jenis dan frekuensi makanan secara langsung dan tidak langsung menjadi penyebab terjadinya masalah kurang gizi (Sufnidar, 2010). Pemberian makanan yang terlalu banyak kepada bayi, terutama susu, justru membuat kantong kemih kencang pada malam hari, 
sehingga akan membuat bayi lebih sering terbangun (Sunarmiati, 2011). Kualitas dan kuantitas tidur yang kurang berdampak negatif terhadap kemampuan berkonsentrasi, fungsi kognitif, perilaku, dan emosional (Anon, 2012). Dampak masalah kurang tidur pada balita, untuk fisik adalah gangguan pertumbuhan badannya karena pengeluaran hormon selama tidur menjadi kacau, kerentanan fungsi imun atau daya tahan tubuh, iregulasi sistem endokrin, kegemukan dan mengantuk (Vina \& Vani, 2010). Gangguan tidur pada bayi bila tidak tertangani dengan baik dapat mengganggu pertumbuhan dan perkembangan bayi (Wirda, 2009).

Berdasarkan penelitian yang dilakukan oleh The NICHD Early Child Care Research di Amerika pada bayi usia 6-15 bulan menunjukkan untuk bayi usia 6 bulan yang mengalami masalah tidur sebanyak 53\% sedangkan untuk bayi usia 15 bulan sebanyak 44\% (PMcNamara et al., 2003). Data di Indonesia cukup banyak bayi yang mengalami masalah tidur, yaitu sekitar $44,2 \%$. Lebih dari $72 \%$ orang tua tidak menganggap gangguan tidur pada bayi sebagai suatu masalah (Sitiatava, 2011). Penelitian yang sama dilakukan oleh Sukartini tahun 2004, di Indonesia, dari 80 anak berusia kurang dari 3 tahun, 41 diantaranya atau 51,3\% mengalami gangguan tidur. Berdasarkan penelitian yang ditujukan pada 385 responden di lima kota besar di Indonesia yakni Jakarta, Bandung, Medan, Palembang, dan Batam terungkap 44,2\% mengalami gangguan tidur yaitu jam tidur malamnya kurang dari 9 jam, terbangun malam hari lebih dari 3 kali dan lama terbangun lebih dari 1 jam ( Roekistiningsih.dkk, 2006).

Upaya yang bisa dilakukan tenaga kesehatan sebagai edukator adalah dengan memberikan penyuluhan dan pendidikan kesehatan untuk membantu ibu dan keluarga mendapatkan pemahaman dan ketrampilan yang tepat dalam memberikan intake nutrisi pada bayi (MGS, 2011). Selain itu, petugas kesehatan juga harus melakukan tindak lanjut dari penyuluhan yang sudah dilakukan seperti melaksanakan kunjungan rumah untuk mengetahui bagaimana pemberian makan yang dilakukan oleh orang tua khususnya ibu bayi meliputi jenis makanan, frekuensi makanan, dan banyaknya makanan yang dikonsumsi sehingga bisa diketahui apakah ibu sudah melakukan pemenuhan nutrisi yang tepat atau belum. Selain itu, orang tua secara psikologis harus memberi perhatian dan dorongan baik langsung maupun dari sikap seperti menciptakan keharmonisan, menjaga hubungan antara anggota keluarga yang baik. Bagi orangtua hal penting lainnya adalah memperhatikan jadwal tidurnya (Widodo, 2009). Penelitian ini dilakukan untuk mengetahui hubungan pemenuhan gizi dengan kualitas tidur pada bayi usia 6-9 bulan di Puskesmas Bangsal Kabupaten Mojokerto.

\section{METODE}

Penelitian ini merupakan penelitian analitik yang bertujuan mengungkapkan hubungan antarvariabel. Sedangkan rancang bangun peneitian menggunakan cross sectional yang merupakan rancangan penelitian yang pengukuran atau pengamatannya dilakukan secara simulan pada satu saat. Hipotesis penelitian adalah terdapat hubungan antara pemenuhan gizi dengan kualitas tidur pada bayi 6-9 bulan di Puskesmas Bangsal Kabupaten Mojokerto.

Variabel independen dalam penelitian ini adalah pemenuhan gizi pada bayi usia 6-9 bulan. Variabel dependent pada peneltian ini adalah kualitas tidur pada bayi usia 6-9 bulan. Populasi penelitian adalah bayi usia 6-9 bulan di Puskesmas Bangsal Kabupaten Mojokerto pada bulan Maret 2020 sebanyak 49 bayi. Sedangkan besar sampel yang diambil adalah bayi usia 6-9 bulan sebanyak 39 bayi dengan teknik non probability sampling yaitu total sampling. Penelitian dilaksanakan di Puskesmas Bangsal Kabupaten Mojokerto pada bulan Maret sampai Mei 2020. Data yang digunakan adalah data primer. Teknik pengumpulan data dengan melakukan wawancara pada ibu bayi dengan menggunakan instrumen penelitian berupa lembar wawancara. Analisis data dilakukan dengan Uji Chi Kuadrat atau X². 
HASIL

1. Karakteristik Responden

a. Umur

Tabel 1. Distribusi Frekuensi Usia Bayi di Puskesmas Bangsal Kabupaten Mojokerto pada Maret 2020

\begin{tabular}{|c|c|c|c|}
\hline No. & Usia & Frekuensi (f) & Prosentasi (\%) \\
\hline 1. & 6 bulan & 14 & 35,9 \\
\hline 2. & 7 bulan & 4 & 10,3 \\
\hline 3. & 8 bulan & 10 & 25,6 \\
\hline 4. & 9 bulan & 11 & 28,2 \\
\hline . & mlah & 39 & 100 \\
\hline
\end{tabular}

Berdasarkan tabel 1 di atas paling banyak bayi di Puskesmas Bangsal Kabupaten Mojokerto berusia 6 bulan sebanyak 14 (35,9\%).

b. Jenis Kelamin

Tabel 2. Distribusi Frekuensi Jenis Kelamin Bayi di Puskesmas Bangsal Kabupaten Mojokerto pada Maret 2020

\begin{tabular}{|c|c|c|c|}
\hline No. & Jenis Kelamin & Frekuensi (f) & Prosentasi $(\%)$ \\
\hline 1. & Laki-laki & 23 & 59,0 \\
\hline 2. & Perempuan & 16 & 41,0 \\
\hline & Jumlah & 39 & 100 \\
\hline
\end{tabular}

Berdasarkan tabel 2 di atas lebih dari setengah bayi di Puskesmas Bangsal Kabupaten Mojokerto berjenis kelamin laki-laki sebanyak 23 bayi (59,0\%).

c. Kondisi Kesehatan

Tabel 3 Distribusi Frekuensi Kondisi Kesehatan Bayi di Puskesmas Bangsal Kabupaten Mojokerto pada Maret 2020

\begin{tabular}{|l|c|c|c|}
\hline No. & Kondisi Kesehatan & Frekuensi (f) & Prosentasi (\%) \\
\hline 1. & Sehat & 39 & 100 \\
\hline 2. & Sakit & 0 & 0 \\
\hline \multicolumn{2}{|c|}{ Jumlah } & 39 & 100 \\
\hline
\end{tabular}

Berdasarkan tabel 3 di atas keseluruhan bayi di Puskesmas Bangsal Kabupaten Mojokerto kondisinya sehat sebanyak 39 (100\%).

\section{Data Khusus}

a. Pemenuhan Gizi

Tabel 4 Distribusi Frekuensi Pemenuhan Gizi Bayi di Puskesmas Bangsal Kabupaten Mojokerto pada Maret 2020

\begin{tabular}{|c|c|c|c|}
\hline No. & Pemenuhan Gizi & Frekuensi (f) & Prosentasi (\%) \\
\hline 1. & Lebih & 9 & 23,1 \\
\hline 2. & Cukup & 12 & 30,8 \\
\hline 3. & Kurang & 18 & 46,2 \\
\hline \multicolumn{2}{|c|}{ Jumlah } & 39 & 100 \\
\hline
\end{tabular}


Berdasarkan tabel 4. paling banyak bayi di Puskesmas Bangsal Kabupaten Mojokerto pemenuhan gizinya kurang sebanyak 18 bayi (46,2\%).

b. Kualitas Tidur

Tabel 5 Distribusi Frekuensi Kualitas Tidur Bayi di Puskesmas Bangsal Kabupaten Mojokerto pada Maret 2020

\begin{tabular}{|c|c|c|c|}
\hline No. & Kualitas Tidur & Frekuensi (f) & Prosentasi (\%) \\
\hline 1. & Ada Gangguan Tidur & 25 & 64,1 \\
\hline 2. & $\begin{array}{c}\text { Tidak Ada Gangguan } \\
\text { Tidur }\end{array}$ & 14 & 35,9 \\
\hline \multicolumn{2}{|c|}{ Jumlah } & 39 & 100 \\
\hline
\end{tabular}

Berdasarkan tabel 5 di atas sebagian besar bayi di Puskesmas Bangsal Kabupaten Mojokerto kualitas tidurnya mengalami gangguan tidur sebanyak 25 bayi $(64,1 \%)$.

c. Hubungan Pemenuhan Nutrisi dengan Kualitas Tidur Bayi

Tabel 6 Tabulasi Silang Pemenuhan Gizi dengan Kualitas Tidur Bayi Usia 6-9 Bulan di Puskesmas Bangsal Kabupaten Mojokerto pada Maret 2020

\begin{tabular}{|c|c|c|c|}
\hline \multirow{2}{*}{$\begin{array}{c}\text { Pemenuhan } \\
\text { Gizi }\end{array}$} & \multicolumn{3}{|c|}{ Kualitas Tidur } \\
\cline { 2 - 4 } & Ada Gangguan Tidur & Tidak Ada Gangguan Tidur & Jumlah \\
\hline \multirow{2}{*}{ Lebih } & 9 & 0 & 9 \\
\cline { 2 - 4 } & $23,1 \%$ & $0 \%$ & $23,1 \%$ \\
\hline \multirow{2}{*}{ Cukup } & 1 & 11 & 12 \\
\cline { 2 - 4 } & $2,6 \%$ & $28,2 \%$ & $30,8 \%$ \\
\hline \multirow{2}{*}{ Kurang } & 15 & 3 & $46,2 \%$ \\
\cline { 2 - 4 } & $38,5 \%$ & $21,4 \%$ & 39 \\
\hline \multirow{2}{*}{ Jumlah } & 25 & 14 & $100 \%$ \\
\cline { 2 - 4 } & $64,1 \%$ & $35,9 \%$ & $b 2 \% 1$ \\
\hline
\end{tabular}

Berdasarkan hasil tabulasi silang pada tabel 6 di atas dapat diketahui bahwa bayi yang pemenuhan gizinya lebih dan mengalami gangguan tidur sebanyak $9(23,1 \%)$, bayi dengan pemenuhan gizinya cukup dan tidak mengalami gangguan tidur sebanyak $11(28,2 \%)$, sedangkan bayi yang pemenuhan gizinya kurang yang mengalami gangguan tidur sebanyak $15(38,5 \%)$.

Hasil uji Pearson Chi-Square dengan menggunakan SPSS di dapat nilai $\mathrm{P}_{\text {Value }}$ Cremer's $V$ sebesar 0,000 , maka nilai $\mathrm{P}_{\text {Value }}<\alpha(0,05)$. Sehingga dapat disimpulkan bahwa $\mathrm{H}_{1}$ diterima yang berarti terdapat hubungan antara pemenuhan gizi dengan kualitas tidur pada bayi usia 6-9 bulan di Puskesmas bangsal Kabupaten Mojokerto.

\section{PEMBAHASAN}

Menurut data didapatkan paling banyak bayi usia 6-9 bulan yang mengalami pemenuhan gizi kurang sebanyak 18 (46,2\%). Menurut Hidayat (2015), pemenuhan gizi pada bayi usia 69 bulan merupakan poses menggunakan makanan yang dikonsumsi secara normal pada anak usia 6-9 bulan. Kecukupan pemenuhan gizi bayi dapat dilihat dari berapa banyaknya makanan, jenis makanan, maupun frekuensi makanan yang dikonsumsinya.

Menurut Husaini (2012) melalui makanan manusia mendapatkan zat gizi yang merupakan kebutuhan dasar manusia untuk tumbuh dan berkembang. Bayi setelah lahir 
sebaiknya diberikan ASI, seiring dengan tumbuh kembang diperlukan makanan pendamping ASI (Taufan, 2011). Saat pemberian makanan pada bayi perlu diperhatikan ketepatan waktu pemberian, frekuensi, jenis, jumlah bahan makanan, cara pembuatannya (Asdan, 2018).

Berdasarkan data menunjukan dari 39 bayi usia 6-9 bulan, lebih dari setengah bayi mengalami gangguan tidur sebanyak 25 bayi $(64,1 \%)$.

Menurut Candra (2005) kualitas tidur adalah keadaan fisiologis tertentu yang didapatkan selama seseorang tidur, yang memulihkan proses-proses tubuh yang terjadi pada waktu orang itu bangun. Jika kualitas tidurnya bagus artinya fisiologi tubuh dalam hal ini sel otak misalnya pulih kembali seperti semula saat bangun tidur.

Kualitas tidur bayi adalah tidur nyenyak pada bayi yang diperlihatkan dengan berapa lama tidur bayi dalam 24 jam, jumlah tidur siang, keadaan saat tidur, dan gangguan tidur pada bayi (Roekiatiningsih. dkk, 2006).

Tidur berperan penting dalam tumbuh kembang normal, kesehatan emosi dan fungsi imun, pertumbuhan dan pemulihan jaringan tubuh, pembelajaran dan pemrosesan memori, serta perbaikan sistem saraf pusat. Pada saat tidur akan memberikan kesempatan bagi otot untuk istirahat. Ketika tidur tubuh direstorasi (diperbaiki), yang dicirikan oleh rendahnya kesadaran dan keadaan metabolisme tubuh minimal. Secara otomatis, otak memprogram untuk tidur saat hari mulai gelap, kemudian terbangun ketika terang (Sitiatava, 2011).

Semakin bertambahnya usia, tidur aktif juga akan semakin berkurang. Besaran jumlah jam tidur anak, disesuaikan dengan tingkatan umurnya. Pada usia 6-9 bulan memerlukan waktu tidur sekitar 14 jam perhari. Bayi mungkin melakukan satu atau dua kali tidur siang per hari, yaitu sekali di pagi hari dan sekali di sore hari (Vinadanvani, 2010).

Hasil uji Pearson Chi-Square dengan menggunakan SPSS di dapat nilai $\mathrm{P}_{\text {Value }}$ Cremer's $V$ sebesar 0,000 , maka nilai $\mathrm{P}_{\text {Value }}<\alpha(0,05)$. Sehingga dapat disimpulkan bahwa $\mathrm{H}_{1}$ diterima yang berarti terdapat hubungan antara pemenuhan gizi dengan kualitas tidur pada bayi usia 69 bulan.

Faktor penting untuk memaksimalkan periode emas pertumbuhan otak adalah terpenuhinya gizi dan kecukupan tidur bayi. Bayi yang sulit tidur atau sering terbangun dari tidurnya karena merasa belum kenyang. Karena itu, penuhi kebutuhan makan dan minum bayi sebelum tidur. Selain itu, memberikan makanan terlalu banyak pada bayi terutama susu akan membuat kantong kemih kencang pada malam harinya dan kedaan ini akan membuat bayi lebih sering terbangun. Jika kebutuhan fisiknya dipenuhi secara cukup, bayi tidak lagi sering terbangun di tengah malam. Hal terebut menunjukkan bahwa kualitas tidur bayi buruk (Sitiatava, 2011).

Kualitas tidur bayi tidak hanya berpengaruh pada perkembangan fisik, tapi juga sikapnya keesokan hari. Bayi yang tidur cukup tanpa sering terbangun akan lebih bugar dan tidak gampang rewel Ciri-ciri bayi cukup tidur, yaitu, ia akan dapat jatuh tertidur dengan mudah di malam hari, bugar saat bangun tidur, tidak rewel, dan tidak memerlukan tidur siang yang melebihi kebutuhan sesuai dengan perkembangannya. Perkembangan kognitif bayi yang mengalami gangguan tidur akan terganggu. Bayi akan tumbuh menjadi anak yang kurang perhatian dan konsentrasi, kurang waspada, bereaksi lambat, dan mempunyai daya memori rendah (Sitiatava, 2011).

\section{KESIMPULAN}

Terdapat hubungan antara pemenuhan gizi dengan kualitas tidur pada bayi usia 6-9 bulan di Puskesmas bangsal Kabupaten Mojokerto.

Bagi tenaga kesehatan khususnya bidan untuk memberikan edukasi kepada orangtua tentang pemenuhan gizi yang tepat dan kebutuhan tidur pada bayi sekaligus memantau perkembangannya dengan melakukan kunjungan rumah untuk melakukan evaluasi. 


\section{REFERENSI}

Anon. (2012). Kualitas Tidur Bayi Penentu Kecerdasan Otak. (http://kualitas-tidur-bayipenentu-kecerdasan-otak.html, diakses 14 Desember 2019).

Arikunto, Suharsimi. (2016). Prosedur Penelitian Suatu Pendekatan Praktik (Edisi Revisi). Jakarta: PT. Rineka Cipta.

Aryo. (2018). Gizi Kurang pada Balita. (http://www.gizi.net/komposisi/index.shtml, diakses 14 Desember 2019).

Dahlan, Sopiyudin. (2019). Besar Sampel dan Cara Pengambilan Sampel dalam Penelitian Kedokteran dan Kesehata, Edisi 2. Jakarta: Salemba Medika.

Dodi. (2019). Data Nilai Satuan Ukuran Rumah Tangga. (http://happydesug.blogspot.com, diakses 14 Desember 2019).

Hidayat, A. Azis Alimul. (2010). Riset Keperawatan dan Teknik Penulisan dan Ilmiah. Jakarta: Salemba Medika.

Judarwanto. (2019). Gangguan Tidur pada Anak. (http:// GANGGUAN TIDUR PADA ANAK « CHILDREN SLEEP CLINIC.htm, diakses 14 Desember 2019).

Kurniati, Irma \& Nugraheni, Mutia. (2009). Kualitas Tidur Pengaruhi Sikap Anak. (http:// kualitas_tidur_pengaruhi_sikap_anak.htm, diakses 14 Desember 2019).

Lusa. (2019). Gizi Seimbang bagi Bayi. (http://Gizi Seimbang Bagi Bayi_Gizi_.htm, diakses 04 April 2012).

MGS. (2011). Hubungan Pemberian ASI Eksklusif dengan Status Gizi Bayi Usia 0-6 bulan di Desa Menganti. (http://www.hubungan-pemberian-asi-eksklusif-dengan.html, diakses 14 Desember 2019).

Nursalam. (2011). Konsep dan Penerapan Metodologi Penelitian Ilmu Keperawatan Pedoman Skripsi, Tesis, dan Instrumen Penelitian Keperawatan Edisi 2. Jakarta: Salemba Medika.

Notoatmodjo, Soekijdo. (2010). Metodologi Penelitian Kesehatan. Jakarta: Rineka Cipta.

Rizema, Sitiatava. (2019). Tips Sehat dengan Pola Tidur yang Tepat dan Cerdas. Jakarta: EGC.

Robert, Yin. (2014). Studi Kasus Desain dan Metode. Jakarta: PT. Raja Grafindo.

Sugiyono. (2017). Statistik untuk Penelitian. Bandug: CV. Alvabeta.

Sari, Wahyuni. (2011). Asuhan Neonatus, Bayi, \& Balita:Penuntun Belajar Praktek Klinik. Jakarta: EGC.

Sumarmiati. (2010). Pengaruh Pemijatan terhadap Efektifitas Tidur Bayi. (http:// pengaruhpemijatan-terhadap-efektifitas.html, diakses 14 Desember 2019).

Vina \& Vani. (2010). Kualitas Tidur Sangat Penting bagi Pertumbuhan Anak.. (http:// kualitastidur-sangat-penting-bagi-pertumbuhan-anak.html, diakses 14 Desember 2019).

Wirda, Hayati \& Aslis. (2019). Gizi Bayi: Buku Saku. Jakarta: EGC.

Yamin, Sofyan \& Kurniawan, Heri.( 2011). SPSS COMPLETE: Teknik Analisis Statistik Terlengkap dengan Software SPSS. Jakarta: Salemba Infotek 